\title{
Titonostalgia w wydaniu tabloidowym. Postać Josipa Broza-Tity na łamach gazety „24 Sata”
}

Abstract

Titonostalgia in Tabloid Release. The Figure of Josip Broz-Tito on the Pages of "24 Sata"

The paper is based on the observation of the phenomenon of yugo- and titonostalgia in the Croatian mass culture, which, combined with the policy of infotainments resulted in a highly interesting way of presenting Josip Broz-Tito in the daily newspaper "24 Sata".

The picture of Marshal Tito that is emerging from published articles, is positive in general. One will not find a critical analysis of his achievements or commentaries on the controversial points of his governments, as the tabloid focuses on gossips and anegdotes from his highly interesting life. According to the profile of the newspaper, most of the articles refers to his amorous conquests, love life, luxury and great wealth. A large part of them are also his newly disclosed secrets the public had no clue about, but those also do not apply to the sphere of serious politics, but rather give another sneak-peak into marshal's private area. This image, although rather positive, sometimes even proud, is really shallow, one-sided, commoditized, and aims to attract a common reader.

Keywords: Tito, tabloid, infotainment, yugonostalgia, titonostalgia, Yugoslavia.

Słowa kluczowe: Tito, tabloid, infotainment, jugonostalgia, titonostalgia, Jugosławia.

Inspiracją dla powstania niniejszego tekstu była obserwacja zjawiska jugoi titonostalgii w przestrzeni chorwackiej kultury masowej, które w połączeniu z polityką infotainments zaowocowało wysoce interesującym sposobem przedstawiania postaci Josipa Broza-Tity. Materiałem do badań stały się teksty opublikowane w internetowym wydaniu gazety codziennej „24 Sata”, będącej chorwackim odpowiednikiem polskiego „Super Ekspresu” czy „Faktu”, a więc wydawnictwa, w stosunku do którego można z pełnym przekonaniem użyć określenia ,tabloid". Publikacje występujące w powyższym serwisie w większości pokrywały się $\mathrm{z}$ materiałem dostępnym w numerach drukowanych. Wybór strony internetowej 
jako źródła informacji spowodowany został możliwością nieograniczonego dostępu do materiałów.

Jeśli przyjrzeć się współczesnym mediom, w sposób nieunikniony nasuwa się spostrzeżenie, że polityka w ujęciu masowym stała się w obecnych czasach pop-polityką. Dominuje skracanie dystansu i rezygnacja z głębszych treści na rzecz miłej, płytkiej rozrywki, co związane jest ściśle z ponowoczesną kulturą, daleką od promowania sztywnych wzorów czy wysokiego standardu, skupiającą się raczej na rynkowej, niż edukacyjnej stronie informacji. Najważniejszym problemem działaczy sceny politycznej jest kwestia medialnego wizerunku - popularność i rozpoznawalność przekłada się bezpośrednio na miejsce w partyjnej hierarchii i głosy wyborców. Liczy się to, co można przekształcić w produkt i sprzedać, nawet jeśli informacja rozmija się z prawdą.

Tabloid to gazeta codzienna o formacie mniejszym od normalnego, tania, mająca duże nagłówki i kolorowe zdjęcia, lekką i często sensacyjną treść. Warto przy tym zaznaczyć, że polski odpowiednik tego anglicyzmu - „gazeta brukowa” - to leksem nacechowany pejoratywnie, tabloid zaś takiego nacechowania nie ma. Jego obecność w polszczyźnie w formie oryginalnej jest więc uzasadniona. Stał się on również podstawą rzeczownika „tabloidyzacja”, którym określić można upodabnianie się do tabloidu, czyli ujmowanie zjawisk w sposób mający na celu poszukiwanie sensacyjnej treści i jej eksponowanie bez głębszego wnikania w istotę relacjonowanych faktów.

Tabloid mający swe historyczne źródła w obszarze prasy rozprzestrzenił się, jako formuła komunikowania, na wszelkie dostępne media. I choć istnieją na rynku medialnym typowe i właściwe klasycznym tabloidom wydawnictwa prasowe jak Fakt, The Sun czy Bild (w odmianie internetowej będzie to np. najpopularniejszy w Polsce serwis plotkarski pudelek.pl), to właściwości tabloidowych narracji przenikają do tzw. głównego nurtu¹.

Cechą tabloidalnych wypowiedzi dziennikarskich jest mieszanie faktów i opinii ${ }^{2}$. Z ludzkiego punktu widzenia relacjonowane i oceniane są zdarzenia interesujące „zwykłych” ludzi, np. plotki i fakty z życia gwiazd i różnej maści celebrytów, skandale, afery, zbrodnie. Wydarzenia podlegają więc swoistej selekcji - im bardziej sensacyjne, tym ważniejsze. Walery Pisarek pisze o:

strategii udramatyzowanego opowiadania, upraszczającego i personalizującego stan rzeczy; uwaga skupia się raczej na osobach niż na ich działaniu; w selekcji wydarzeń większą rolę niż ich społeczna ważność odgrywa sensacyjność i zdolność do wywoływania wrażenia ${ }^{3}$.

Znacznie wcześniej, w latach 60. ubiegłego wieku, Daniel Boorstin zauważył, że wśród dziennikarzy i wydawców zaczął pojawiać się zwyczaj informowania o zdarzeniach nieprawdziwych bądź podkolorowywania informacji uznanych za mało ciekawe:

1 B. Dziadzia, Tabloidyzacja na peryferiach. Doksa i stygmat prowincji [w:] Transdyscyplinarność badań nad komunikacją medialna, t. 3: Tożsamość dziennikarza, red. M. Kita, M. Ślawska, Katowice 2013, s. 72.

2 W. Pisarek, Wstęp do nauki o komunikowaniu, Warszawa 2008, s. 134.

3 Ibid. 
Ponieważ koszty druku stawały się coraz większe, z przyczyn ekonomicznych stało się konieczne utrzymanie gazet i stacji telewizyjnych w ciągłym ruchu. Presja w kierunku tworzenia wydarzeń stawała się coraz silniejsza. Zbieranie informacji przemieniło się w ich kreowanie ${ }^{4}$.

Kreatorzy wypowiedzi w formule infotainment uwzględniają preferencje masowej publiczności (w tym akceptację potocznego pojęcia normy oraz gotowości do ekonomizowania wysiłku w sytuacji nadmiaru przekazów medialnych, a często także lenistwa umysłowego), konkurencję z innymi mediami, akceptację porządku społecznego i głównego nurtu kultury, czyli kultury popularnej. Jednym z tematów, które bardzo dobrze spełniają wymogi stawiane im przez współczesne szybkie i płytkie media, jest titonostalgia - nacechowany tęsknotą za dawnymi czasami kult marszałka Josipa Broza-Tity. Podobnie rzecz się ma z jugonostalgią, pojęciem szerszym, ponieważ konotującym nie tylko pozytywne uczucia w stosunku do osoby charyzmatycznego wodza, lecz także sentyment za (względnie) bezpiecznymi, (pozornie) stabilnymi czasami i wysokim - w porównaniu z innymi państwami socjalistycznymi - standardem życia.

Jugonostalgia, jak również titonostalgia, to fenomen łączący tych, dla których koniec Jugosławii był osobistym dramatem, zerwaniem ciągłości życia i utratą poczucia stabilności i dobrobytu, z przedstawicielami młodszych pokoleń, którzy jugosłowiański komunizm znają jedynie z podręczników historii i narracji wspomnieniowej i którzy postrzegają tę epokę jako modną i fascynującą. Z podobną nostalgią za czasami komunistycznymi możemy się zetknąć również $\mathrm{w}$ innych dawnych państwach byłego bloku wschodniego,' w tym w Polsce, gdzie buty Relaks, bary mleczne i gadżety nawiązujące do czasów PRL-u straciły znamiona siermiężności i cieszą się wśród młodych konsumentów dużą popularnością.

Po ponad 20 latach od rozpadu Jugosławii, po okresie deprecjonowania, zjawisko jugonostalgii przestało mieć negatywne konotacje i zyskało drugie życie, także w sensie komercyjnym. W Belgradzie działa Muzeum Historii Jugosławii, gdzie na cykliczne wystawy przybywają rzesze zainteresowanych, a w Suboticy powstał Jugoland, park tematyczny będący Jugosławią w miniaturze. Wydawnictwa takie jak SFRJ za ponavljače czy Emigrantski kuvar cieszą się dużą popularnością. Ex-Jugosłowianie nie tęsknią jednak wyłącznie za dawnym wspólnym krajem, lecz także, a niekiedy przede wszystkim, za jego przywódcą.

Josip Broz-Tito, postać barwna, charyzmatyczna, wielowymiarowa, to osoba, której kult trwał nieprzerwanie od lat 50. ubiegłego wieku i - jak można zauważyć - utrzymuje się do dzisiaj. Jak zauważa Pero Simić w książce Tito - zagadka stulecia:

Pokoleniom jugosłowiańskich obywateli wpajano od małego, że to on daje siłę załamanym, rozpogadza posępnych, pociesza stroskanych, wzmacnia słabych, dźwiga upadłych, tworzy bohaterów, a analfabetów zamienia w ludzi oświeconych. Że to on jest naszym jedynym drogowskazem. I że każdy, który pójdzie za nim tam, dokąd on zmierza, dotrze tam dzień przedtem, nim wyruszy $1^{5}$.

4 D.J. Boorstin, The Image. A Guide to Pseudo-Events in America, New York 1992, s. 14.

5 P. Simić, Tito-zagadka stulecia, przeł. D. Ćirlić-Straszyńska, D.J. Ćirlić, Wrocław 2011, s. 12. 
Dla ukształtowania się obecnie istniejącego kultu wodza istotny jest też fakt, że światowa opinia publiczna również nie była obojętna na jego czar. Amerykanie nazywali go „dominującą postacią światowej sceny politycznej”, Afrykanie „patriarchą niezaangażowanych”, Anglicy „,symbolem XX wieku”, a niemiecki kanclerz Willy Brandt uznał Titę za „dar losu”. Przyznano mu również tytuł doktora honoris causa na uczelniach w Birmie, na Filipinach, w Chile, Algierii, Etiopii i Mongolii ${ }^{7}$. Jedynym wyróżnieniem, którego marszałek nie dostał, była Pokojowa Nagroda Nobla, do otrzymania której zabrakło mu jednego głosu ${ }^{8}$. Przez dziesiątki lat wychwalali go i podziwiali nawet ci, którzy nie wiedzieli, gdzie dokładnie Jugosławia się znajduje; opinie nieprzychylne, jak ta sformułowana przez poprzednika Brandta, kanclerza Konrada Adenauera, który nazwał go „zwykłym bandytą", były nielicznymi wyjątkami w powszechnie obowiązującym dyskursie.

W kraju, jako pierwszemu nadawano mu tytuły honorowego obywatela jugosłowiańskich gmin. Jego patronatem objęte były organizacje naukowe, twórcze i społeczne. Był również doktorem honoris causa wszystkich jugosłowiańskich uniwersytetów i szkół wyższych, a także prezesem wszystkich klubów sportowych.

Josip Broz-Tito w kontrolowanych przez partię mediach jugosłowiańskich przedstawiany był na różne sposoby, w zależności od doraźnych potrzeb, ale zawsze w pozytywnym kontekście. Wszystkie prezentacje podporządkowane były kultowi jego osoby i miały utwierdzać obywateli w przekonaniu o doskonałości prezydenta. Historycy ustalili, że istnieje 19 motywów, z którymi kojarzy się postać marszałka:

1. Motiv lidera siromašnog i seljačkog podrijetla

2. Motiv odgovornog lidera

3. Motiv radničkog lidera

4. Motiv lidera s ratnim iskustvom

5. Motiv komunističkog lidera

6. Motiv lidera priznate povijesne uloge

7. Motiv osloboditelja

8. Motiv zaštitnika

9. Motiv nositelja idološkog pravovjerja

10. Motiv donositelja napretka

11. Motiv omiljenog lidera

12. Motiv državnog objednitelja

13. Motiv svjetski priznatog političara

14. Motiv borca za mir

15. Motiv borca za ravnopravnost i mirnu koegzistenciju naroda

16. Motiv uspješnog diplomata

17. Motiv dostojanstvenog vladara

18. Motiv naroda blisko vlade

19. Motiv vitalnog lidera ${ }^{9}$

6 Ibid., s. 15.

7 Ibid., s. 269.

8 Ibid., s. 284.

9 „1. Motyw lidera pochodzącego z biednej wsi. 2. Motyw odpowiedzialnego lidera. 3. Motyw robotniczego lidera. 4. Motyw lidera z doświadczeniem wojennym. 5. Motyw komunistycznego lidera. 
Wymienione motywy miały na celu stworzenie konkretnego wizerunku Broza-Tity w świadomości społeczeństwa jugosłowiańskiego, ale też przypisanie prezydentowi konkretnych cech osobowości. Miały mu też zapewnić prestiż jako politycznemu liderowi i potwierdzić legitymację do sprawowania najwyższego urzędu w państwie. Działo się to nie tylko poprzez nadawanie mu konkretnych atrybutów o pozytywnych konotacjach, ale też przez prezentowanie go jako postaci niemal mitycznej. Identyfikowano go z hasłami takimi jak: naród, wolność czy młodość. Uważa się, że podtrzymywanie kultu Tity związane było w mniejszym stopniu z jego pracą nad budową silnego państwa, a w większym z działaniami jego politycznego zaplecza. Wyniesienie go do roli ponadprzeciętnego wodza było wynikiem atmosfery panującej w społeczeństwie jugosłowiańskim, żyjącym w przekonaniu, że kieruje nim charyzmatyczny lider ${ }^{10}$.

Od chwili, kiedy 4 maja 1980 roku wszystkie telewizje i radio w byłej Jugosławii podały informację, że umarł drogi towarzysz Tito, minęło ponad 35 lat. Jego postać jednak do dzisiaj jest obecna w codziennym życiu obywateli wszystkich republik byłej Jugosławii. Marszałek istnieje medialnie, tak jakby była mowa o żyjącej osobie, swego rodzaju celebrycie, postaci z estrady i pierwszych stron gazet. Fenomen Tity trudno jest wyjaśnić w sposób naukowy czy chociażby zdroworozsądkowy.

Dzisiejsza przychylność w stosunku do marszałka ma zupełnie inne źródła niż kiedyś. W czasach jego rządów kult jego osoby był obowiązkowy, z góry narzucony przez reżim. Obecnie titonostalgia zakłada natomiast dobrowolne zaangażowanie $^{11}$. Broz stał się symbolem bezpieczeństwa i stabilizacji, a w trudnych czasach ludzie tęsknią za charyzmatycznym przywódcą. Marszałek w tego typu dyskursie określany jest jako wielki przywódca partyzantów, kosmopolita i obywatel świata, ostatni z Habsburgów czy jedyny prawdziwy Jugosłowianin. Jego zwolennicy porównują go do Henryka VIII, Marcina Lutra lub tytułują jako ,bałkańskiego Cezara"12. Odwoływanie się do byłego prezydenta jest również przejawem tęsknoty za minionymi czasami i krajem określanym - w nawiązaniu do postaci jego charyzmatycznego przywódcy - „Titolandem” lub „Titosławią”.

Po latach legenda ożywa na nowo. Tito stał się elementem kultury popularnej i jest stale obecny w dyskursie publicznym. Nawiązania do jego osoby można odnaleźć w mass mediach, Internecie, reklamach, piosenkach, filmach czy książkach. Bardzo często na pierwszych stronach gazet zamieszczane są artykuły dotyczące dopiero co odkrytych informacji z prywatnego życia marszałka, opowieści na temat żon, kochanek czy nieślubnych dzieci. Często o jego życiu prywatnym

\footnotetext{
6. Motyw lidera o uznanej roli historycznej. 7. Motyw wyzwoliciela. 8. Motyw obrońcy. 9. Motyw posiadacza kodeksu ideologicznego. 10. Motyw nosiciela postępu. 11. Motyw ukochanego lidera. 12. Motyw zjednoczyciela państwa. 13. Motyw uznanego w świecie polityka. 14. Motyw bojownika o pokój. 15. Motyw bojownika o równouprawnienie i pokojową koegzystencję narodów. 16. Motyw odnoszącego sukcesy dyplomaty. 17. Motyw dostojnego władcy. 18. Motyw narodu blisko władzy. 19. Motyw witalnego lidera", Z. Despot, Tito. Tajne vladara. Najnoviji prilozi za biografiju Josipa Broza, Zagreb 2009, s. 41 [Wszystkie tłumaczenia, jeśli nie podano inaczej, pochodzą od autorki artykułu].

10 Ibid., s. 41.

11 M. Velikonja, Titostalgija, Beograd 2010, s. 41.

12 Ibid., s. 15.
} 
wypowiadają się ludzie z jego imponującej służby: kucharki, mechanicy samochodowi, pokojówki czy ogrodnicy, a ich relacje traktowane są jako najbardziej wiarygodne. Na podstawie materiału zebranego na internetowych stronach dziennika „24 Sata” można odnieść wrażenie, że przeciętny chorwacki konsument nie jest szczególnie zainteresowany historycznie obiektywną, naukowo podpartą analizą rządów Josipa Broza-Tity, co nie znaczy bynajmniej, że nie intryguje go sama postać marszałka. Spośród 172 wyników wyszukiwania w internetowym archiwum tabloidu znakomita większość odnosi się do życia uczuciowego jugosłowiańskiego przywódcy, jego stylu życia, kontaktów ze światem show-biznesu i wielkimi osobistościami światowej polityki. Przez wszystkie przypadki odmienia się imię jego ostatniej żony, Jovanki, drobiazgowo analizując tajemnice ich alkowy.

Tito od czasu objęcia władzy w państwie lubił korzystać z życia i otwarcie przyznawał, że nie urodził się ascetą. Znany był ze swojego zamiłowania do luksusu, a do tego miał słabość do kobiet. Do dzisiaj krążą legendy o jego licznych kochankach, żonach i dzieciach. Według różnych szacunków miał sześć żon, trzy córki i 16 synów. Opinii publicznej znani są tylko dwaj: Žarko i Miša.

Jednym z pierwszych artykułów, które pojawiają się wśród wyników wyszukiwania, jest tekst Borisa Rašety z 10 marca 2010 roku Titove ljubavi: okružio se ženama, ali nije bio sretan (Miłości Tity: otaczat się kobietami, ale nie byt szczęśliwy), w którym już w podtytule czytelnik dowiaduje się, że „Josip Broz je imao četiri ljubavi, no mnogi misle da je najviše volio Zdenku. Umrla je od tuberkuloze 1947., a Tito ju je pokopao u dvorištu rezidencije" "13. Z relacji byłej małżonki Tity, Herty Haas, na którą powołuje się w artykule dziennikarz „24 Sata”, wyłania się obraz fascynującego, szarmanckiego mężczyzny, który dzięki eleganckiemu sposobowi ubierania się i ogromnym pokładom pewności siebie unikał kontroli policyjnych, szmuglując tajne dokumenty, m.in. z Istambułu. Informacja ta nie jest jednak w żaden sposób rozszerzona, gdyż już w następnym akapicie czytamy, że ten „Henryk ósmy samorządowego socjalizmu” zostawił Hertę dla Davorjanki Paunović, czyli wspomnianej Zdenki. Tekst kończy konkluzja, że liczne panie mocno konkurowały o jego uwagę, on zaś kochał ich dziesiątki.

Do tego samego wydarzenia nawiązuje kolejny tekst, opublikowany 3 maja 2010 roku, Tajna Kuće cvijeća: Tita su pokopali uz najveću ljubav (Tajemnica Domu Kwiatów. Pochowali Tito obok jego największej mitości). Ponownie podtytuł dopowiada czytelnikowi: „Tito nije prežalio svoju ljubav iz partizana. Grob joj je uz njegovu vilu na Dedinju u Beogradu. Prije 30 godina je i on tamo pokopan"14. Jak, zdaniem redaktorów „24 Sata”, twierdzą „liczni biografowie Tity”, właśnie

13 „Josip Broz miał cztery miłości, jednak wielu sądzi, że najbardziej kochał Zdenkę. Zmarła na gruźlicę w 1947 r., a Tito pochował ją na dziedzińcu rezydencji”, B. Rašeta, Titove ljubavi: okružio se ženama, ali nije bio sretan, http://www.24sata.hr/news/titove-ljubavi-okruzio-se-zenama-ali-nije-bio-sretan-163080 (dostęp: 20.01.2017).

14 „Tito nie odżałował swojej partyzanckiej miłości. Jej grób znajduje się przy jego willi na Dedinju w Belgradzie. Przed trzydziestoma laty i on został tam pochowany”, HM, BR, Tajna Kuće cvijeća: Tita su pokopali uz najveću ljubav, http://www.24sata.hr/news/tajna-kuce-cvijeca-tita-su-pokopali-uz-najvecu-ljubav-171440 (dostęp: 20.01.2017). 
z powodu pięknej partyzantki, która znana była z głośnego uprawiania miłości (co skwapliwie odnotowuje przywołany w artykule Miro Simčić, autor książki Žene u Titovoj sjeni), marszałek nie został pochowany na cmentarzu. Przy okazji można się dowiedzieć, że Tito poza wspomnianą już charyzmą miał nerwy ze stali - ze Zdenką uprawiał miłość w namiocie, gdy wokół padały granaty. Dalsza część artykułu nieco bardziej wymagającego czytelnika może wprowadzić w zdumienie - to zbiór krótkich, jednozdaniowych informacji, które trudno połączyć w spójną całość. Kolejno:

ZDENKA JE BILA PRVA Davorjanka Paunović bila je punih 29 godina mlađa od šefa jugoslavenskih komunista, ali to se nije pokazalo preprekom. Zdenka, kako su je zvali, imala je veliki utjecaj na Tita. Navodno se Tito u jednoj sobi morao odlučiti između nje i Herte Haas, ali je rekao: ,Riješite to same'. U Vrdoljakovoj seriji Zdenku glumi Zrinka Cvitešić. SLOVENKU HERTU HASS JE OSVOJIO ELEGANCIJOM Titova nevjenčana supruga Herta, s kojom je dobio sina Mišu, nedavno je umrla u Beogradu. Tito ju je osvojio šarmom i elegancijom. Pričala je da je na nju snažan dojam ostavilo jedno Titovo odijelo koje joj se činilo preskupo za jednog komunista, no kasnije je uočila da odijelo nije bilo skupo, nego mu je sjajno stajalo. Od Jovanke Broz Tito je, pak, ponekad morao bježati u kupaonu kako bi mirno spavao.

DOBIO OZIRISA, A DAO SUHE ŠLJIVE! Egipćanin Anvar el Sadat Titu je darovao neprocjenjivo vrijednu statuu Ozirisa, a Tito njemu 50 kila suhih šljiva, sok od ribizle i borovnice te $150 \mathrm{~kg}$ jabuka.

ZASADIO HRASTOVE JOHNA LENNONA Yoko Ono i John Lennon pedesetorici državnika i Titu poslali su 1969. godine po dva žira da zasade hrastove mira. Tito ih je i zasadio u jednom vrtu u Beogradu.

TITO: BIO BIH NAJVEĆI KAPITALIST Na jednom prijmu Tito je razgovarao s gradonačelnikom Hamburga. Rekao mu je: ,Da sam živio u kapitalizmu, bio bih najveći kapitalist'. Mnoge je odgovor iznenadio.

FOTOGRAFIRAO, TOKARIO, SVIRAO Josip Broz Tito obožavao je fotografirati. To mu je bio omiljeni hobi, no volio je i raditi i na tokarskom stroju. Ustajao je svakog jutra u pet. Navodno je svirao klavir ${ }^{15}$.

15 „ZDENKA BYŁA PIERWSZA. Davorjanka Paunović była o całe 29 lat młodsza od szefa jugosłowiańskich komunistów, ale to nie było preszkodą. Zdenka, jak ją nazywali, miała wielki wpływ na Tito. Podobno Tito w jakimś pokoju musiał wybrać między nią a Hertą Haas, ale powiedział: 'Same to załatwcie'. W serialu Vrdoljaka Zdenkę gra Zrinka Cvitešić. / SŁOWENKĘ HERTĘ HASS ZDOBYŁ ELEGANCJĄ. Konkubina Tity, Herta, z którą miał syna Mišę, zmarła niedawno w Belgradzie. Tito zdobył ją szarmanckością i elegancją. Mówiła, że silne wrażenie wywarł na niej jego garnitur, który wyglądał na zbyt drogi jak na jakiegoś komunistę, lecz później zauważyła, że garnitur nie był drogi, tylko świetnie leżał. Natomiast przed Jovanką Broz Tito musiał niekiedy uciekać do łazienki, by pospać w spokoju. / OTRZYMAŁ OZYRYSA, A DAŁ SUSZONE ŚLIWKI! Egipcjanin Anvar el Sadat podatował Ticie bezcenną statuę Ozyrysa, a Tito jemu 50 kilo suszonych śliwek, sok z porzeczek i jagód oraz $150 \mathrm{~kg}$ jabłek. / POSADZIŁ DĘBY JOHNA LENNONA. Yoko Ono i John Lennon wysłali w 1969 roku pięćdziesięciu przywódcom, w tym Ticie, po dwa żołędzie, by zasadzili dęby pokoju. Tito zasadził je w pewnym ogrodzie w Belgradzie. / TITO: BYŁBYM NAJWIĘKSZYM KAPITALISTĄ. Na jednym przyjęciu Tito rozmawiał z burmistrzem Hamburga. Powiedział mu: 'Gdybym żył w kapitalizmie, byłbym największym kapitalistą'. Wielu ta odpowiedź zaskoczyła. / FOTOGRAFOWAŁ, BYŁ TOKARZEM, GRAŁ NA INSTRUMENTACH. Josip Broz Tito uwielbiał fotografować. To było jego ukochane hobby, ale lubił też ślusarkę. Wstawał codziennie o piątej. Podobno grał na fortepianie", Ibid. 
Ten zbiór powiązanych jedynie postacią marszałka informacji nie jest w żaden sposób skomentowany, nie są to także zapowiedzi ewentualnych następnych tekstów.

Kolejne tytuły podtrzymują sławę Broza-Tity jako zdobywcy kobiecych sercartykuł traktujący o życiu seksualnym marszałka na podstawie powieści Stjepana Đurekovića Ja, Josip Broz Tito zatytułowany jest Tito je imao grupni seks s grupom slovenskih balerina? (Czy Tito uprawiat seks grupowy z grupa słoweńskich balerin?: ${ }^{16}$. Tekst w całości dotyczy tego jakże pobudzającego wyobraźnię wydarzenia, a kończy się „ważną" informacją - o tej i innych seksualnych przygodach wodza przeczytać będzie można w publikacji „Śmiercionośne książki o Ticie”, którą znajdziemy w każdym kiosku za jedyne 19.90 kun.

Aby jednak przeciętny Chorwat nie poczuł się szczególnie przytłoczony porównaniem do tak sprawnego seksualnie bohatera, „24 Sata” serwuje od czasu do czasu informacje, które zdejmują marszałka z seksualnego piedestału, w czym pomaga dosyć negatywny wizerunek ostatniej żony Tity, Jovanki. W artykułach określana jest ona jako „histeryczna Lady Makbet”, która zniszczyła życie swojego męża i całkowicie nim zawładnęła w imię własnych interesów i ambicji politycznych. Zarzuca się jej manipulacje, kłamstwa i intrygi, jak również to, że najzwyczajniej, „po babsku” męża tłamsiła. Czytelnik może się zatem dowiedzieć, że: „Tito je glumio frajera, a bio je papak koji se bojao Jovanke” (Tito udawał lovelasa, a był prostakiem, który bał się Jovanki) ${ }^{17}$, „Mogao se nositi sa svima osim sa ženom Jovankom" (Umiał radzić sobie ze wszystkimi, poza żoną Jovanką) ${ }^{18}$, „Pojavila se snimka iz 1975., na kojoj Jovanka Tita zove 'sine"” (Pojawił się film z 1975 r., na którym Jovanka nazywa Titę „synem”) ${ }^{19}$ itp. Sama Jovanka również gościła często na łamach tabloidu, opowiadając o tym, jak rekwirowano osobiste rzeczy jej męża, zastraszano ją, wtargnięto do jej domu w poszukiwaniu tajnych dokumentów z czasów Jugosławii, a przy okazji ukradziono kosztowności, dzieła sztuki i cenne pamiątki. Jak twierdziła, czuła zagrożenie ze strony wrogów obawiających się, że zacznie zdradzać niewygodne tajemnice z przeszłości.

Ticie zdarzały się również wpadki wizerunkowe: z tekstu Raheli Štambuk Našli fotografiju gologuzog druga Tita u Španjolskoj? (Znaleźli ujęcie towarzysza Tito z golym tyłkiem w Hiszpanii? $)^{20}$ dowiedzieć się można, że w 1961 roku w albumie o uczestnikach hiszpańskiej wojny domowej pojawiło się zdjęcie z 1939 roku, na którym późniejszy marszałek prezentuje swój całkowicie nagi tył. Fakt przytrzaśnięcia mu palców drzwiami od samochodu w 1976 roku podczas wizyty w Szwecji odnotowany został z kolei w artykule 'Jaooooo, to baš boli': zalupio

16 A. Mlačak, Tito je imao grupni seks s grupom slovenskih balerina?, http://www.24sata.hr/news/ tito-je-imao-grupni-seks-s-grupom-slovenskih-balerina-340134 (dostęp: 20.01.2017).

17 B. Rašeta, Tito je glumio frajera, a bio je papak koji se bojao Jovanke, http://www.24sata. $\mathrm{hr} /$ news/tito-je-glumio-frajera-a-bio-je-papak-koji-se-bojao-jovanke-326619 (dostęp: 20.01.2017).

18 B. Rašeta, Mogao se nositi sa svima osim sa ženom Jovankom, http://www.24sata.hr/news/ mogao-se-nositi-sa-svima-osim-sa-zenom-jovankom-164488 (dostęp: 20.01.2017).

19 A. Mlačak, Pojavila se snimka iz 1975. na kojoj Jovanka Tita zove 'sine', http://www.24sata. $\mathrm{hr} /$ news/pojavila-se-snimka-iz-1975-na-kojoj-jovanka-tita-zove-sine-340962 (dostęp: 20.01.2017).

20 R. Štambuk, Našli fotografiju gologuzog druga Tita u Španjolskoj?, http://www.24sata.hr/ news/nasli-fotografiju-gologuzog-druga-tita-u-spanjolskoj-77274 (dostęp: 20.01.2017). 
vratima i Titu prikliještio prste (Ojoj, jak boli! Trzasnąt drzwiami i przykleszczyt Ticie palce) $)^{21}$.

W gazecie „24 Sata” pojawiają się informacje dotyczące kontaktów Tity ze światem show-biznesu, bogactwa czy domniemanych tajemnic złożonych w sejfie w gabinecie marszałka, jednak najczęstszym tematem związanym z Titą są mimo wszystko jego kobiety. Obszerny artykuł Borisa Rašety z kwietnia 2014 roku, Otkrivamo velike ljubavne tajne Josipa Broza: sve Titove žene, po raz kolejny traktuje o miłościach marszałka - przywołuje wiadomości doskonale już regularnym czytelnikom dziennika znane; nowością jest informacja, że do grona kobiet nim oczarowanych zaliczyć można również brytyjską królową Elżbietę, która $\mathrm{z}$ jego powodu złamała protokół dyplomatyczny i kilkakrotnie zatańczyła z Titą podczas uroczystej kolacji. $Z$ artykułu można się również dowiedzieć, że w kwestiach ekonomicznych Broz wiele nauczył się od Herty Haas, że z powodu Zdenki chciał wyrzec się członkostwa w partii komunistycznej, zaś jego ostatnia żona, Jovanka, zgotowała mu prawdziwe piekło na ziemii, tak że „u zadnje vrijeme njihova zajedničkog života Tito živio lošije od beogradskih klošara. Jovanka je uspjela fizički rastjerati sve zdravstveno i kućno osoblje, nije više bilo ni maserki, ni liječnika, ni kuharice...”22.

Jak zauważają liczni badacze problemu tabloidyzacji współczesnych mediów, tematami, które zawsze się sprzedają, poza seksem, są zbrodnia i sensacja. Dziwić może, że w przypadku obecności Tity na łamach dziennika „24 Sata” temat jego zbrodni jest niemal całkowicie pomijany, a sensacyjne odkrycia w większości dotyczą jego życia uczuciowego, ewentualnie zawartości sejfu. Niemniej w sierpniu 2013 roku chorwacką przestrzenią medialną zatrzęsła informacja, którą skwapliwie przekazał również tabloid: CIA zaključila: Tito je bio Rus ili Poljak, nije bio Jugoslaven. Analitycy CIA na podstawie mowy marszałka z 1977 roku przeprowadzili analizę językową, na podstawie której stwierdzili, że miał on obcy akcent, rosyjski lub polski, lecz z pewnością nie urodził się w Jugosławii.

Sensacyjna informacja nie była jednak pierwszą. Już na początku maja 2013 roku na łamach tabloidu dziennikarka Jelena Pešorda w artykule Teorije urote: Josipa Broza Tita zamijenio je tajni agent? przedstawia tezę, że Josipa Broza zabito w latach 20. (odpowiednio: w Moskwie, na Sutjesce bądź w czasie desantu na Drvar), więc Komintern wysłał w jego miejsce swego szpiega, polskiego szlachcica. Dowodów na potwierdzenie tej teorii było wiele i wszystkie stanowiły w czasach Jugosławii prawdziwą tajemnicę poliszynela: prawdziwy Tito stracił w dzieciństwie palec (albo trzy), a po powrocie z wojny znowu miał ich komplet, nagle potrafił świetnie grać na fortepianie, doskonale posługiwał się literacką odmianą języka (a „prawdziwy” Tito był ślusarzem i miał kłopoty z przypadkami), no i oczywiście - miał nietypowy akcent. Mimo że niektóre pomysły dotyczące rodowodu Tity przekraczają granice absurdu, wciąż pojawiają się nowe.

21 I. Živko, 'Jaooooo, to baš boli': zalupio vratima i Titu prikliještio prste, http://www.24sata. hr/news/jaooooo-to-bas-boli-zalupio-vratima-i-titu-priklijestio-prste-334473 (dostęp: 20.01.2017).

22 B. Rašeta, Otkrivamo velike ljubavne tajne Josipa Broza: sve Titove žene, http://www.24sata. $\mathrm{hr} /$ news/otkrivamo-velike-ljubavne-tajne-josipa-broza-sve-titove-zene-359669 (dostęp: 20.01.2017). 
Innym, naprawdę szeroko komentowanym na łamach „24 Sata” tematem było otwarcie po ponad 30 latach słynnego sejfu, mającego zawierać majątek przywódcy Jugosławii. To, co znajdowało się w skrytce bankowej, zelektryzowało obywateli byłej Jugosławii do tego stopnia, że niemal każdy chciał wiedzieć, co jest w środku. Media roztaczały wokół domniemanego skarbu aurę tajemniczości i zapowiadały ujawnienie wielkiego sekretu marszałka. Należy przy tym odnotować, że w tej sytuacji Tito przedstawiany był raczej w sposób negatywny. Chociaż do czasu wyjaśnienia zagadki nie było żadnych oficjalnych informacji, dziennikarze w swoich relacjach sugerowali, że ewentualna tajemnica Tity wiąże się z czymś złym i niekorzystnie wpłynie na jego wizerunek. Kontrowersje wywołane zawartością skarbca były jeszcze większe przez spór o to, kto ma prawo dziedziczyć odkryte dobra. Pretensje do majątku rościła sobie przede wszystkim rodzina marszałka, twierdząc, że zawartość sejfu to mienie należące niegdyś do Broza, a nie do państwa jugosłowiańskiego. Temat „skarbu Tity” nie bez przyczyny elektryzował społeczeństwo, okazał się bowiem imponujący:

U sefu je 30-tak kilograma zlata, 2663 velikih i malih zlatnika, 13 odlikovanja obitelji Karađorđević, 251 predmeta od zlata i drugih plemenitih metala, 83 sitnijih predmeta od zlata poput medaljona, kutija za cigarete, dugmadi, oko 26 tisuća dolara i 36 tisuća njemačkih maraka, 149 predmeta od zlata, briljanata i dijamanata u vlasništvu obitelji Karađorđević, 18 kompleta srebrnih i pozlaćenih servisa i pribora za jelo te 1271 komada novca numizmatičke vrijednosti ${ }^{23}$.

Podczas analizy zgromadzonego materiału można się natknąć na nieliczne, zazwyczaj rocznicowe artykuły, podejmujące bezpośrednio temat titonostalgii, z których na uwagę zasługuje Maršal je odavno mrtav, a štafete mu i dalje dolaze (Marszatek nie żyje od dawna, a sztafety nadal biegna dla niego). W krótkim tekście wspomniano Dom Kwiatów, miejsce jego pochówku i popularny turystyczny cel wycieczek (73 tysiące odwiedzających), oraz doroczną sztafetę młodzieży z okazji Dnia Radości, urodzin Marszałka. Tym, co wyróżnia ten artykuł spośród wielu podobnych mu tekstów „rocznicowych”, odnotowujących w paru zdaniach fenomen nieustającego czczenia pamięci wodza, jest krótkie, w formie plusów i minusów, podsumowanie jego rządów. Analizę tę ograniczono w każdym przypadku do pięciu podpunktów wraz z jedno-, dwuzdaniowym rozwinięciem:

\section{PLUSEVI:}

1. SPASIO NAS OD HITLERA I STALJINA Josip Broz Tito predvodio je antifašistički pokret. Spriječio je ulazak Jugoslavije u Varšavski pakt i tamnicu realnog komunizma pod Staljinom.

2. VRATIO OTOKE, ZADAR, RIJEKU I ISTRU Hrvatskoj je vratio dijelove koje je Ante Pavelić ustupio Italiji, te pripojio Istru i Rijeku.

${ }^{23}$ „W sejfie jest 30 kilogramów złota, 2663 dużych i małych złotych monet, 13 portretów rodziny Karađorđević, 251 przedmiotów ze złota i innych metali szlachetnych, 83 drobnych przedmiotów ze złota, na przykład medaliony, papierośnica, guziki, około 26 tysięcy dolarów i 36 tysięcy marek niemieckich, 149 przedmiotów ze złota, brylantów i diamentów, nalezących do rodziny Karađorđević, 18 kompletów srebrnych i pozłacanych serwisów i sztućców oraz 1271 monet posiadających wartość numizmatyczną", VLM, I Karađorđevići traže svoje dragocjenosti iz Titova sefa, http://www.24sata. hr/svijet/i-karaorevici-traze-svoje-dragocjenosti-iz-titova-sefa-335475 (dostęp: 20.01.2017). 
3. VIŠI STANDARD Tito je samo od SAD-a dobio stotinjak milijardi dolara bespovratne pomoći kako bi od SFRJ načinio antisovjetski propagandni izlog.

4. UGLED U SVIJETU On je bio najugledniji državnik s ovih prostora ikad. Na pogreb su mu došli svi.

5. OMOGUĆIO SAMOSTALNOST Ustavom iz 1974. republikama je dao zakonski temelj za izlazak iz SFRJ.

\section{MINUSI:}

1. JEDNOPARTIJSKA DIKTATURA Tito je uveo sustav diktature proletarijata i ukinuo stranke, mada je zapadnim vođama tijekom rata tvrdio da to neće učiniti.

2. ODGOVORAN ZA BLEIBURG I KRIŽNI PUT Deseci tisuća ustaša i domobrana, ali i hrvatskih civila likvidirani su bez suda u Austriji, Sloveniji i Hrvatskoj.

3. LIKVIDACIJA ANDRIJE HEBRANGA Andrija Hebrang smaknut je pod misterioznim okolnostima, vjerojatno prema Titovu nalogu ili uz njegovu suglasnost.

4. GUŠENJE DEMOKRACIJE Ugušio je Hrvatsko proljeće, smijenio srpske liberale, slovenske reformiste...

5. POLITIČKI SUDOVI Suđenja zbog različitog mišljenja, kult ličnosti, progoni zbog sitnica... ${ }^{24}$

W tym wypadku najbardziej chyba uderza brak jakiejkolwiek krytycznej refleksji, jednak zarzut braku pogłębionej czy choćby pobieżnej analizy postaci i wydarzeń można odnieść do każdego z prezentowanych tekstów.

Po przeanalizowaniu zgromadzonego materiału można uznać, że obraz marszałka Tity, wyłaniający się z opublikowanych artykułów, jest generalnie pozytywny. Relacje na jego temat nie są krytyczną analizą dokonań czy komentarzem do kontrowersyjnych rządów, ale skupiają się na plotkach i anegdotkach z jego barwnego życia. Zgodnie z profilem gazety większość artykułów dotyczy jego miłosnych podbojów, wielkiego majątku i pozostałości po nim. Sporą część stanowią również dopiero ujawniane tajemnice, o których opinia publiczna nie miała dotąd pojęcia, jednak również one nie dotyczą poważnej polityki, ale raczej strefy prywatnej czy towarzyskiej. Obraz ten jest płytki, jednostronny, utowarowiony i nastawiony na przyciągnięcie czytelników, których takie podejście do złożonej i wielowymiarowej sylwetki marszałka najwyraźniej całkowicie satysfakcjonuje.

\section{Bibliografia}

Boorstin D.J., The Image. A Guide to Pseudo-Events in America, New York 1992.

Despot Z., Tito. Tajne vladara. Najnoviji prilozi za biografiju Josipa Broza, Zagreb 2009.

Dziadzia B., Tabloidyzacja na peryferiach. Doksa i stygmat prowincji [w:] Transdyscyplinarność badań nad komunikacja medialna, t. 3: Tożsamość dziennikarza, red. M. Kita, M. Ślawska, Katowice 2013.

Pisarek W., Wstęp do nauki o komunikowaniu, Warszawa 2008.

Simić P., Tito - zagadka stulecia, przeł. D. Ćirlić-Straszyńska, D.J. Ćirlić, Wrocław 2011.

Velikonja M., Titostalgija, Beograd 2010.

24 HM, BR, Maršal je odavno mrtav, a štafete mu i dalje dolaze, http://www.24sata.hr/news/ marsal-je-odavno-mrtav-a-stafete-mu-i-dalje-dolaze-171443 (dostęp: 20.01.2017). 
Źródła internetowe

HM, BR, Maršal je odavno mrtav, a štafete mu i dalje dolaze, http://www.24sata. $\mathrm{hr} /$ news/marsal-je-odavno-mrtav-a-stafete-mu-i-dalje-dolaze-171443 (dostęp: 20.01.2017).

HM, BR, Tajna Kuće cvijeća: Tita su pokopali uz najveću ljubav, http://www.24sata. hr/news/tajna-kuce-cvijeca-tita-su-pokopali-uz-najvecu-ljubav-171440 (dostęp: 20.01.2017).

Mlačak A., Pojavila se snimka iz 1975. na kojoj Jovanka Tita zove 'sine', http:// www.24sata.hr/news/pojavila-se-snimka-iz-1975-na-kojoj-jovanka-tita-zove-sine-340962 (dostęp: 20.01.2017).

Mlačak A., Tito je imao grupni seks s grupom slovenskih balerina?, http://www.24sata. $\mathrm{hr} /$ news/tito-je-imao-grupni-seks-s-grupom-slovenskih-balerina-340134 (dostęp: 20.01.2017).

Rašeta B., Mogao se nositi sa svima osim sa ženom Jovankom, http://www.24sata. hr/news/mogao-se-nositi-sa-svima-osim-sa-zenom-jovankom-164488 (dostęp: 20.01.2017).

Rašeta B., Otkrivamo velike ljubavne tajne Josipa Broza: Sve Titove žene, http:// www.24sata.hr/news/otkrivamo-velike-ljubavne-tajne-josipa-broza-sve-titove-zene-359669 (dostęp: 20.01.2017).

Rašeta B., Tito je glumio frajera, a bio je papak koji se bojao Jovanke, http:// www.24sata.hr/news/tito-je-glumio-frajera-a-bio-je-papak-koji-se-bojao-jovanke-326619 (dostęp: 20.01.2017).

Rašeta B., Titove ljubavi: Okružio se ženama, ali nije bio sretan, http://www.24sata. $\mathrm{hr} /$ news/titove-ljubavi-okruzio-se-zenama-ali-nije-bio-sretan-163080 (dostęp: 20.01.2017).

Štambuk R., Našli fotografiju gologuzog druga Tita u Španjolskoj?, http://www. 24sata.hr/news/nasli-fotografiju-gologuzog-druga-tita-u-spanjolskoj-77274 (dostęp: 20.01.2017).

VLM, I Karađorđevići traže svoje dragocjenosti iz Titova sefa, http://www.24sata. $\mathrm{hr} /$ svijet/i-karaorevici-traze-svoje-dragocjenosti-iz-titova-sefa-335475 (dostęp: 20.01.2017).

Živko I., 'Jaooooo, to baš boli': Zalupio vratima i Titu prikliještio prste, http:// www.24sata.hr/news/jaooooo-to-bas-boli-zalupio-vratima-i-titu-priklijestio-prste-334473 (dostęp: 20.01.2017). 